\title{
SLOVAK COMPARATIVE CORRELATIVES: NEW INSIGHTS
}

\author{
JAKOB HORSCH \\ Catholic University of Eichstätt-Ingolstadt, Germany
}

HORSCH, Jakob: Slovak comparative correlatives: New insights. Journal of Linguistics, 2019, Vol. 70, No 2, pp. $180-190$.

\begin{abstract}
Comparative Correlatives (CCs) are structures that have attracted substantial interest. In Slovak, they typically look like the following proverb:

Čím bližšie Rím, tým horši krestian.

'The closer (to) Rome, the worse the Christian.'

So far, no extensive research has been conducted on CCs in Slavic languages except Polish [1]. In Slovak, CCs have not received a great deal of attention. Accordingly, this study examines the various forms of CCs in a Slovak National Corpus (SNC) random sample of 500 tokens, showing that there is much more variety than has been acknowledged in the literature. Frequencies will be used to show that there are iconic structures, and it will be argued that there are construction-specific properties that suggest the existence of a specific CC construction in Slovak.
\end{abstract}

Keywords: Slovak, Comparative Correlative, Slovak National Corpus

\section{INTRODUCTION}

The comparative correlative (CC), also known as comparative conditional [2], proportional correlative [3] and the... the... construction [4], is a highly interesting structure that has seen increased attention [1], [3], [5-9]. Most of this research has focused on English, neglecting the Slavic languages (an exception is Borsley's study of Polish CCs [1]), which differ significantly from English with regard to basic parameters such as word order.

In its most simple form, the $\mathrm{CC}$ construction consists of two clauses, $\mathrm{C} 1$ and C2. It appears that this basic form is comparable across many languages [10], as the following examples illustrate for English (1) [11], Slovak (2), Polish (3) [1] and German (4) [5]:

(1) [The more carefully you do your work, $]_{\mathrm{C} 1}[\text { the easier it will get. }]_{\mathrm{C} 2}$

(2) [Č́m menej reči tu bude, $]_{\mathrm{C} 1}[\text { tým skôr zaspím. }]_{\mathrm{C} 2}$

'The less talking there is here, the sooner I will fall asleep.'

$<$ SNC prim-7.0-public-all JTol2>

(3) [Im bardziej zmęczony jesteś, $]_{\mathrm{C} 1}[t y m \text { gorzej pracujesz. }]_{\mathrm{C} 2}$

'The more tired you are, the worse you work.' 
(4) [Je müder Otto ist, $]_{\mathrm{C} 1}[\text { desto agressiver ist er. }]_{\mathrm{C} 2}$

'The more tired Otto is, the more aggressive he is.'

Semantically, CCs are complex: $\mathrm{C} 2$ can be described as the effect (or apodosis/ dependent variable) of $\mathrm{C} 1$ (the corresponding protasis/independent variable) [12], [13]. More precisely, the semantic properties are both asymmetric as well as symmetric: On the one hand, there is a conditional, or asymmetric, relationship, i.e., in example (1) getting together results in happiness, and on the other hand, there is parallel change over the same time period, i.e., by getting together more and more, happiness simultaneously increases. Sag refers in this context to a "pair of semantic differentials" coupled with a "monotonic relationship" [9].

Concerning the form, each clause is introduced by fixed, i.e., invariable clauseinitial elements; in the case of Slovak čm (C1) and tým (C2). We can also see that these clause-initial elements are followed by comparative elements such as more carefully and easier in English (1), and menej reči and skôr in Slovak (2). Finally, there is the option of inserting a clause after these comparative elements, such as you do your work in $\mathrm{C} 1$ in (1), or zaspim in $\mathrm{C} 2$ in (2).

In other words, this is what Hoffmann refers to as a "constructional template" [7], [14] that produces CCs that vary in complexity: While the clause-initial elements are fixed, there is a slot for comparative elements that can be freely filled and a further slot for clauses that can but doesn't have to be filled.

In various languages, idiosyncracies have been observed in CCs, which has led to increased interest: Borsley, for example refers to the $\mathrm{CC}$ as a "notable peripheral construction" that exhibits phenomena that "fall outside the scope of syntax proper" [1]. In fact, Slovak CCs also exhibit a variety of highly interesting idiosyncracies.

This is why the following study was conducted with evidence from the Slovak National Corpus (SNC). It examines the various forms of Slovak CCs, discussing particularly interesting traits. The aim is to complement the literature, which has so far treated the CC in Slovak marginally: Many of the forms found in the SNC are not mentioned at all in the literature. Authentic examples from a 500 token random sample will showcase the manifold forms CCs can appear in, and by use of frequencies suggest there structures that appear to be clearly preferred over others.

\section{ONLINE DICTIONARIES IN GDC}

\subsection{Slovak CCs in the literature}

So far, no extensive research has been carried out on Slovak CCs. However, they have sporadically attracted interest. The earliest mentioning of the cooccurrence of the clause-initial elements čím and tým can be traced to 1943 [15]. 
In subsequent years, čím-tým as used in CCs was discussed briefly by Betáková and Marsinová. Interestingly, according to Betáková, čím and tým belong to the category of "correlative conjunctions" (súvzt'ažná spojka) [16]. Marsinová, on the contrary, suggests the pair be excluded "a priori" from the category of conjunctions because she considers the word čim not to be related to the conjunction čo [17].

In fact, we can observe general uncertainty concerning the classification of čm and tým as used in CCs: Elsewhere they are classified as "hypotactic conjunctions" (hypotaktická spojka) [18], and other sources state that while they look like the instrumental case forms (siedmy pád) of relative pronouns (súvztažné zámená) čo and to, they have become fossilized as a "pair of conjunctions" (spojková dvojica) which connects "modal clauses of comparison" (spôsobové vety porovnávacie) [19].

In a similar vein, the only longer study on Slovak CCs explicitly excludes čim and tým as they appear in CCs from the group of pronouns and speaks of "particles" (častice) that "modify comparatives" [20], furthermore noting that when tým is eliminated from the structure, čim loses its validity, thereby implying that both of these words are necessary for the structure to carry the distinct CC meaning.

This view also points to the interpretation that will be argued for later, which is that we are looking at fixed clause-initial elements that may be etymologically related to instrumental-case forms of the pronouns $\check{c} o$ and $t o$, but are in fact construction-specific elements.

Further uncertainty in the literature concerns terminology: It appears that there is no agreement on what to call the CC construction in Slovak. Various terms are used, including "modal or comparative adverbial clauses" (spôsobové alebo prirovnávacie vety) [21], "adverbial comparative clause" (príslovková veta prirovnávacia) [22], "comparative clauses" (porovnávacie vety) [23], "comparative modal adverbial clause" (prislovková veta spôsobová - prirovnávacia) [24], [25], and "adverbial subordinate clause of degree" (prislovková vedlajšía veta miery) [26].

This disagreement hints at the marginal status of CCs in research, which is also reflected by the little attention they receive in grammars: While some do briefly mention CCs [21-24], other grammars completely ignore their existence [27], [28]. Even the Morfológia slovenského jazyka devotes no more than one paragraph to the CC [18].

Of course, this makes Slovak CCs all the more interesting. It is also noteworthy that the examples given in the sources above do not suggest a great variety of possible forms. As will be shown, CCs in Slovak actually appear in many forms, suggesting that CCs are a highly productive structure.

Moreover, Slovak CCs possess unique construction-specific properties such as the invariable clause-initial elements discussed above, and obligatory and optional slots that can accommodate material of varying complexity. Together with the lack of research noted earlier, these features certainly warrant an in-depth corpus study. 


\subsection{Corpus Study}

The following study is based on the prim-7.0-public-all version of the SNC, a corpus of written Slovak that consists of $65.1 \%$ journalistic, $15.1 \%$ fiction, $9.5 \%$ professional and $10.3 \%$ other texts, with a size of almost 1 billion words [29]. The following CQL query ${ }^{1}$ using the SNC web interface [30] was used to find cím-tým patterns:

$$
\begin{aligned}
& \text { [word="čím"] [] }\{, 9\}\left[\operatorname{tag}="\left(D *(x|y| z)\left|A^{*}(x|y| z)\right| G^{*}(x|y| z)\right) * *^{*}\right][]^{*}[\text { word=","] } \\
& {\left[\text { word="tým"] [] }\{, 9\}\left[\operatorname{tag}="\left(D *(x|y| z)\left|A^{*}(x|y| z)\right| G^{*}(x|y| z)\right) * * "\right]\right.}
\end{aligned}
$$

In total, this query yielded 10,151 tokens, from which a random sample of 500 tokens was extracted. From these, 17 false positives were determined, leaving 483 relevant $\mathrm{CC}$ tokens.

The first notable characteristic of Slovak CCs that the data shows is their variation in complexity, which examples (5) to (8) from the SNC illustrate:
(5) Čím

$$
\text { d'alej, tým }
$$$$
\text { lepšie. }
$$
ČÍM further TÝM better
'The further/longer, the better.'

$$
<\text { SNC prim-7.0-public-all InZ2/03> }
$$
(6) Č́m viac $k$ športu Č́́M more to sports TÝM more from dangerous ciest (...).
ways

'The more inclination towards sports, the less inclination towards dangerous lifestyles.' $<$ SNC prim-7.0-public-all KOR2001/06>

(7) Č́m viac milujeme, tým viac rastieme $v$ slobode. ČÍM more love:we TÝM more grow:we in freedom 'The more we love, the more we grow in freedom.'

$<$ SNC prim-7.0-public-all MI2010/05>

\begin{tabular}{llllll} 
(8) Č́m & dôkladnejšie & popremýšlate & o svojich krokoch, \\
Č́m & \multicolumn{2}{l}{ thoroughly-more } & think:you:2:PL & about your & steps \\
tým & lepšie to & pre vás & dopadne. & \\
TÝM & better it & for you & results
\end{tabular}

'The more thoroughly you think about your steps, the better it turns out for you.'

$<$ SNC prim-7.0-public-all MYBB2013/36>

${ }^{1}$ I would like to thank my colleague Dr. Thomas Brunner from the Department of English Linguistics at the Catholic University of Eichstätt-Ingolstadt for helping me compose this regular expression. 
As is evident, the complexity of Slovak CCs ranges from very basic constructions with only comparative elements as in (5) (Sabol refers to these as "elliptic" [20], implying the omission of a verb) to complex structures such as (8) that include transitive verbs and prepositional objects. It is interesting that in this context, the Morfológia mentions that following the clause-initial elements, there can be a "word or a clause" (slovo alebo veta) [18], but does not provide examples of complex structures such as (8).

We can thus say that apart from the invariable clause-initial elements čim and tým, the $\mathrm{C} 1$ and $\mathrm{C} 2$ clauses have slots: First, one that contains an obligatory comparative element (e.g. d'alej and lepšie in (5)) following the clause-initial elements čm and tým and second, an optional clause slot that follows the comparative elements, as is demonstrated by (6) to (8). These clauses vary considerably in length and complexity.

Generalizing from these observations, we can thus determine a more abstract schema, or "constructional template" [7, 14] for Slovak CCs (9), based on Culicover and Jackendoff's template for English CCs [10]. Note that the clauseinitial elements ${ }^{2}$ are transcribed in IPA to represent their phonological invariability, as they are assumed to be construction-specific and not related to the pronouns $\check{c} o$ and $t o$.

(9) $\left.\left[[\mathrm{t} f \mathrm{i}: \mathrm{m}][\ldots]_{\text {comp. element }}[\ldots]_{\text {opt. clause }}\right]_{\mathrm{C} 1}[[\mathrm{ti}: \mathrm{m}] \ldots][\ldots]_{\text {comp. element }}[\ldots]_{\text {opt. clause }}\right]_{\mathrm{C} 2}$

Turning to the comparative element, CCs can contain adjectives such as horši in the Slovak proverb Č́m bližšie Rím, tým horší krest'an, adverbs (e.g. viac in (7)), or noun phrases, as in (10):

(10)

$\begin{array}{lllllll}\text { čím } & \text { väčšie } & \text { t'ažkosti treba prekonat, } & \text { tým } & \text { prenikavejšie } \\ \text { ČÍM } & \text { bigger } & \text { problems } & \text { must:he overcome } & \text { TÝM } & \text { brighter } \\ & \text { zažiari } & \text { úspech učitel'a } & & & \\ & \text { shines } & \text { success teacher:GEN } & & \end{array}$

'The bigger the problems that must be overcome, the brighter the success of the teacher shines.'

$<$ SNC prim-7.0-public-all BGal1 $>$

In this context, one variable that was coded for the SNC data was FILLER TYPE, which revealed that there is a strong preference for adverb phrases as comparative elements, as Tables and Figures 1 and 2 show:

${ }^{2}$ The Morfológia notes that in informal language, to may be used instead of tým. [18] 


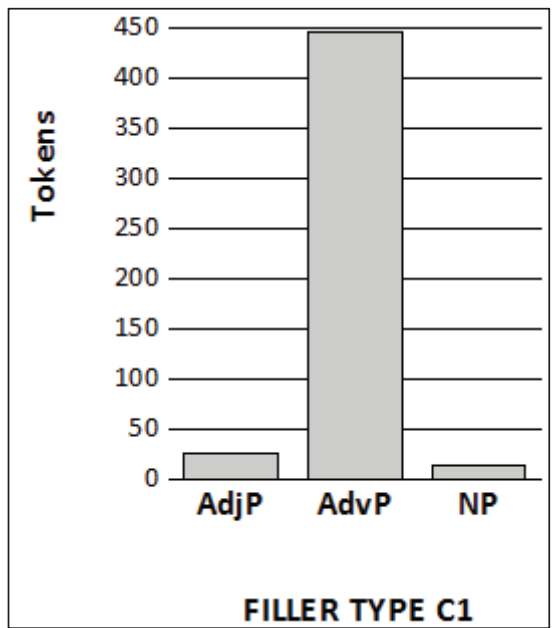

Fig. 1. C1 filler types

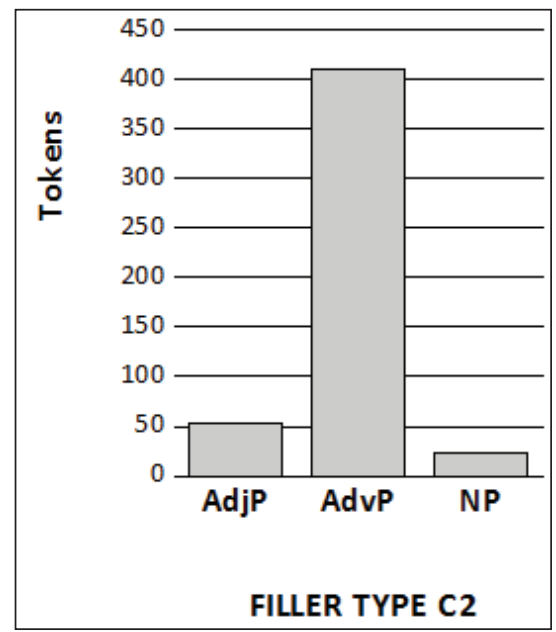

Fig. 2. C2 filler types

\begin{tabular}{|l|l|l|l|}
\hline FILLER TYPE C1 & Tokens & FILLER TYPE & Tokens \\
\hline ADJP & 23 & ADJP & 51 \\
\hline ADVP & 446 & ADVP & 408 \\
\hline NP & 14 & NP & 24 \\
\hline Total & 483 & Total & 483 \\
\hline
\end{tabular}

Tab. 1. C1 filler types

Tab. 2. C2 filler types

The numbers show that both in $\mathrm{C} 1$ and $\mathrm{C} 2$, the majority of comparative elements were adverb phrases, 446 and 408 out of 483, respectively. Nevertheless, there was still a significant number of other filler types, which demonstrates the productivity of the pattern.

Moving on, an interesting feature of Slovak CCs that differentiates them from their English counterparts is the relatively free ordering of constituents. Consider (11) and (12), for example:

$\begin{array}{llllll}\text { č́m } & \text { som } & \text { sa } & \text { viac } & \text { usiloval, } & \text { tým } \\ \text { Čím } & \text { am:I } & \text { sa:REFL } & \text { more } & \text { tried } & \text { TÝM } \\ \text { silnejšie } & \text { sa } & \text { vo } & \text { mne } & \text { táto } & \text { odporná } \\ \text { stronger } & \text { sa:REFL in } & \text { me } & \text { this } & \text { detestable } \\ \text { vlastnost' } & \text { presadzovala. } & & & \\ \text { feature } & \text { asserted } & & & \end{array}$

'The more I tried, the stronger this detestable feature asserted itself in me.' $<$ SNC: prim7.0-public-all SME2009/10> 
(12)

$\begin{array}{llllll}\text { Č́m } & \text { bol } & \text { spisovatel } & \text { odvážzejší, } & \text { tým } & \text { väčši } \\ \text { ČÍM } & \text { was:he } & \text { author } & \text { brave:more } & \text { TYYM } & \text { bigger }\end{array}$

účinok malo jeho dielo. ${ }^{3}$

effect had:it his work

'The braver an author was, the bigger an effect his work had.'

We see that comparative elements do not have to follow the clause-initial elements but can also be found at the center, as in (11) or at the end, as in (12). This means that the template as suggested in (9) is not entirely satisfactory.

As Tables and Figures 3 and 4 illustrate, however, there is a clear tendency towards placing the comparative element in the front position, right after the clauseinitial element (clauses which consist of a comparative element only, as in (5), were omitted from the coding of this variable):

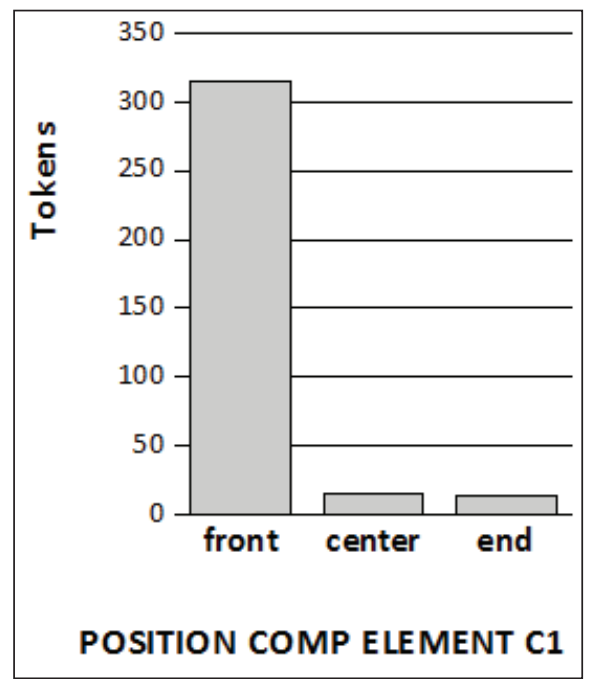

Fig 3. Comparative element position in $\mathrm{C} 1$

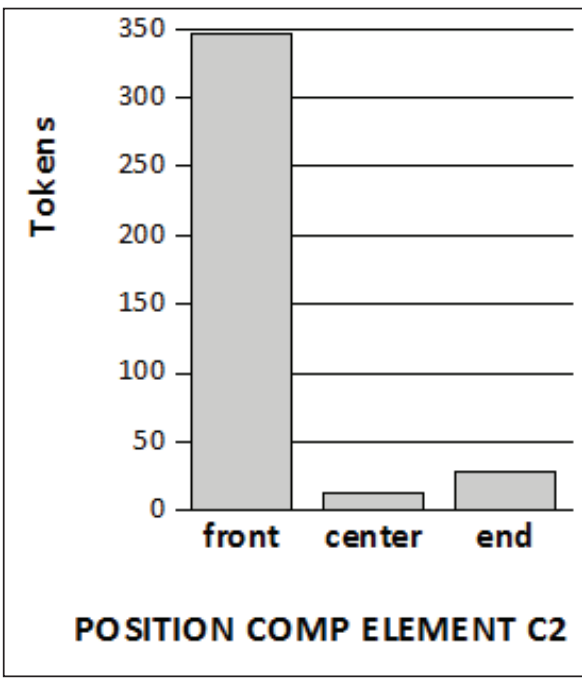

Fig. 4. Comparative element position in $\mathrm{C} 2$

\begin{tabular}{|l|l|l|l|}
\hline $\begin{array}{l}\text { COMPARATIVE EL. } \\
\text { POSITION C1 }\end{array}$ & Tokens & $\begin{array}{l}\text { COMPARATIVE EL. } \\
\text { POSITION C2 }\end{array}$ & Tokens \\
\hline front & 315 & front & 346 \\
\hline center & 15 & center & 12 \\
\hline end & 13 & end & 28 \\
\hline Total & 343 & Total & 386 \\
\hline
\end{tabular}

Tab. 3. Comparative element position in $\mathrm{C} 1$

Tab. 4: Comparative element position in $\mathrm{C} 2$

${ }^{3}$ www.litcentrum.sk/31662 
These numbers show that while the generally free word order of Slovak does apply to the CC construction, there is a clear preference for an order with the comparative element immediately following the clause-initial element, as in (5) to (8). It is noteworthy that this is also the only order discussed in the literature; there is no mentioning of any of the alternatives as in (11) and (12).

Another interesting phenomenon is that of so-called "stacked" constructions, which are also known in English [8], where a CC consists of more than two clauses, as in (13) and (14):

(13) $[A$

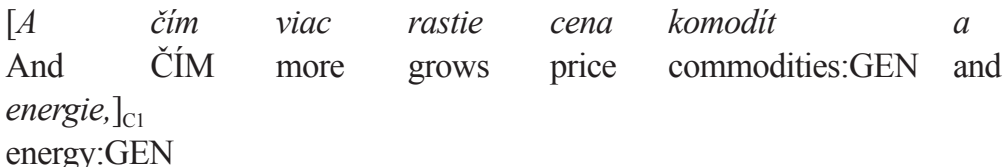

\begin{tabular}{lllll}
{$\left[t^{\prime} m\right.$} & viac & je & \multicolumn{2}{c}{ americká ekonomika "spanikárená", $]_{\mathrm{C} 2}$} \\
TÝM & more & is & American economy "panicked" \\
{$[$ tým } & viac & sa & prepadá do recesie. $]_{\mathrm{C}}$ \\
TÝM & more & sa:REFL sinks:it into recession
\end{tabular}

'And the more the price of commodities and energy grows, the more the American economy panics, the more it sinks into recession.'

$<$ SNC: prim-7.0-public-all HN2008/04>

(14) $[\text { č́m nižšia je akontácia }]_{\mathrm{Cl}}$

ČÍM lower is deposit

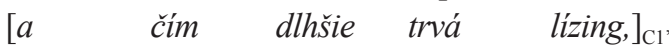

and ČíM longer lasts leasing

[tým drahšie kúpa vyjde. $]_{\mathrm{c} 2}$

TÝM expensive:more purchase becomes

'The lower the deposit is and the longer the leasing lasts, the more expensive the purchase becomes.'

$<$ SNC: prim-7.0-public-all SME04/02>

As these examples show, there are at least two variations of stacked clauses in Slovak: First, there are what we will call $\mathrm{C} 1 \mathrm{C} 2 \mathrm{C} 3$ clauses, as in (13), indicated by the čm-tým-tým clause-initial elements. The semantics of this $\mathrm{CC}$ are as follows: $\mathrm{C} 1$ is the cause for the effect in $\mathrm{C} 2$, which in turn is the cause for the effect in $\mathrm{C} 3$.

Second, there are cases of two causes ( $\mathrm{C} 1$ and $\left.\mathrm{C} 1^{\prime}\right)$ resulting in the same effect (C2), as suggested by the čím-čím-tým clause-initial elements in (14). To paraphrase this $\mathrm{CC}$, the purchase becomes more expensive due to both lower deposits and a longer leasing duration. This is why the designation $\mathrm{C} 1 \mathrm{C} 1{ }^{\prime} \mathrm{C} 2$ is suggested.

Note that neither of these two stacked arrangements in CCs is mentioned in the literature. The reason might be that the SNC data suggests these are not iconic: Out of the $483 \mathrm{CC}$ tokens, only 40 , or just over $8 \%$ were such structures with a clear majority of 443 iconic $\mathrm{C} 1 \mathrm{C} 2 \mathrm{~s}$. 
A further noteworthy feature is reverse, i.e., $\mathrm{C} 2 \mathrm{C} 1$, order. Two such examples were found in the SNC sample as false positives. This phenomenon is known from Polish as well, as Borsley's variation (15) of example (3) [1] demonstrates. In Slovak, C2C1s appear as in example (16).

(15) [Tym gorzej pracujesz, $]_{\mathrm{C} 2}[\text { im bardziej jesteś zmęczony. }]_{\mathrm{C} 1}$ 'The more tired you are, the worse you work.'

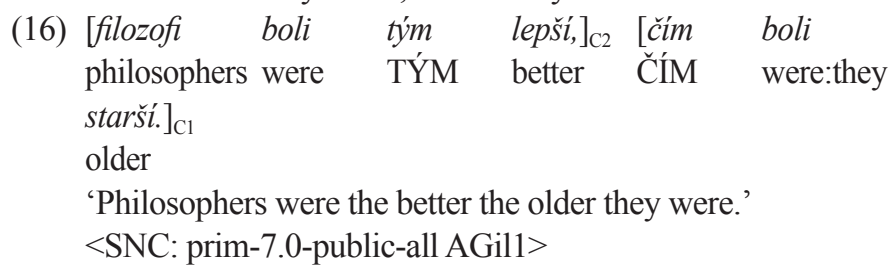

It is notable that such a $\mathrm{C} 2 \mathrm{C} 1$ order is generally not discussed in the literature. While some sources do provide examples [25], these are never discussed with regard to their semantics. Only one source comments on the possible non-iconicity of $\mathrm{C} 2 \mathrm{C} 1 \mathrm{~s}$, noting the $\mathrm{C} 1 \mathrm{C} 2$ order is more or less "consistent" (ustálené) as opposed to the $\mathrm{C} 2 \mathrm{C} 1$ arrangement, which is called an "extraordinary occurrence" (výnimočný jav) [20], thereby implying an iconic $\mathrm{C} 1 \mathrm{C} 2$ structure. Whether such an iconic structure exists in Slovak is a question that must be answered in a future corpus study with a dataset obtained from a regular search expression that includes $\mathrm{C} 2 \mathrm{C} 1 \mathrm{~s}$.

\section{CONCLUSION}

The phenomena discussed in this paper reveal the great variety of forms in which Slovak CCs can appear, far more than the examples provided in the literature to date suggest. Generalizing from the many forms, we can derive a template as suggested in (9), consisting of three slots that follow the words čm and tým.

These words are referred to as "clause-initial elements" here because, as suggested by their phonetic transcription, čim and tým are neither conjunctions of any sort, nor instrumental case pronouns, but rather construction-specific elements that are unique to the Slovak CC: If either is removed, the construction as a whole loses its CC meaning (cf. also [20]).

The template (9) suggested for Slovak CCs is highly productive, leading to the creation of structures that range from very simple, such as (5), to highly complex, such as (8), or even stacked $\mathrm{C} 1 \mathrm{C} 2 \mathrm{C} 3 / \mathrm{C} 1 \mathrm{C} 1{ }^{\prime} \mathrm{C} 2$ structures, as in (13) and (14). Furthermore, $\mathrm{CCs}$ can even appear in inverse $\mathrm{C} 2 \mathrm{C} 1$ order as in (16).

The frequencies determined in the SNC random sample suggest that despite the possibility of variation in Slovak CCs, there are arrangements that are clearly preferred over others: There appears to be a clear preference for adverb phrases in 
the comparative element slot, for placing this element at the front of the clause, and for "iconic" $\mathrm{C} 1 \mathrm{C} 2$ structures as opposed to more complex, stacked ones. These findings confirm the existence of a template as in (9).

The present study has thus managed to shed light on a construction in Slovak that has so far received little attention, despite its many interesting traits. We have been able to show that the Slovak CC is highly productive pattern which produces structures that by far exceed the possibilities that have so far been discussed in the literature, and that it can be regarded as a construction in its own right, with construction-specific properties such as invariable clause-initial elements.

The corpus data provided many more interesting examples, such as interrogative CCs and split fillers that had to be excluded from this study in the interest of brevity. Together with $\mathrm{C} 2 \mathrm{C} 1 \mathrm{~s}$, they could form the base for further research on a highly interesting construction in Slovak.

\section{References}

[1] Borsley, R. D. (2004). On the Periphery: Comparative Correlatives in Polish and English. Proceedings of Formal Approaches to Slavic Linguistics, 12, pages 59-90.

[2] McCawley, J. D. (1988). The Comparative Conditional Construction in English, German, and Chinese. In General Session and Parasession on Grammaticalization. Berkeley Linguistics Society, pages 176-187.

[3] Den Dikken, M. (2005). Comparative Correlatives Comparatively. Linguistic Inquiry, 36(4), pages 497-532.

[4] Cappelle, B. (2011). The the... the... construction: Meaning and readings. Journal of Pragmatics, 43 (1), pages 99-117.

[5] Beck, S. (1997). On the Semantics of Comparative Conditionals. Linguistics and Philosophy, 20 (3), pages 229-271.

[6] Borsley, R. D. (2004). An Approach to English Comparative Correlatives. In Proceedings of the $11^{\text {th }}$ International Conference on Head-Driven Phrase Structure Grammar, Center for Computational Linguistics, Katholieke Universiteit Leuven. Ed. S. Müller, pages 70-92. Stanford, CA: CSLI Publications.

[7] Hoffmann, Th. (2014). Comparing English Comparative Correlatives. Post-doc thesis.

[8] Hoffmann, Th. et al. (2019). The More Data, The Better: A Usage-based Account of the English Comparative Correlative Construction. Cognitive Linguistics, 30(1).

[9] Sag, I.A. (2010). English Filler-Gap Constructions. Language: Journal of the Linguistic Society of America, 86(3), pages 486-545.

[10] Culicover, P. W., and Jackendoff, R. (1999). The View from the Periphery: The English Comparative Correlative. Linguistic Inquiry, 30(4), pages 543-571.

[11] Fillmore, C. J. et al. (1988). Regularity and idiomaticity in grammatical constructions: The case of let alone. Language, pages 501-538.

[12] Goldberg, A. (2005) Constructions at Work. Oxford University Press.

[13] Hoffmann, Th. (2017). Construction Grammar as Cognitive Structuralism: The interaction of constructional networks and processing in the diachronic evolution of English comparative correlatives. English Language and Linguistics, 21(2), pages 349-373. 
[14] Hoffmann, Th. (2019). English Comparative Correlatives: Diachronic and Synchronic Variation at the Lexicon-Syntax Interface. Cambridge, Cambridge University Press.

[15] Vavro, J. (1943). Zo Syntaxe Zámena Čo. Slovenská reč, 10(7-8), pages 222-224.

[16] Betáková, V. (1955). Poznámky k Učebnici jazyka slovenského pre štvorročné odborné školy. Slovenská reč, 20(5), pages 313-323.

[17] Marsinová, M. (1955). Spracovanie gramatických kategórií v normatívnom slovníku. Slovenská reč, 20 (1), pages 29-39.

[18] Dvonč, L. et al. (1966). Morfológia slovenského jazyka. Bratislava, Slovenská akadémia vied.

[19] Oravec, J. (1954). Použivanie slova ‘čo’ v spisovnej slovenčine. Jazykovedný časopis, 8, pages 216-233.

[20] Sabol, F. (1982). Slovo čím v platnosti zámena, Častice a spojky. Slovenská reč, 47(1), pages 51-54.

[21] Pauliny, E. et al. (1963). Slovenská gramatika. Bratislava, Slovenské pedagogické nakladatel'stvo.

[22] Pauliny, E. (1981). Slovenská gramatika (Opis jazykového systému). Bratislava, Slovenské pedagogické nakladatel'stvo.

[23] Stanislav, J. (1977). Slowakische Grammatik. Bratislava, Slowakischer Pädagogischer Verlag.

[24] Mistrík, J. (2003). Gramatika slovenčiny. Bratislava, Slovenské Pedagogické nakladatel'stvo.

[25] Orlovský, J. (1971). Slovenská syntax. Bratislava, Obzor.

[26] Pavlovič, J. (2012). Syntax slovenského jazyka I. Accessible at: http: / / pdf . truni . sk/eucebnice/pavlovic/syntax-1.

[27] Mistrík, J. (1988). A Grammar of Contemporary Slovak. Bratislava, Slovenské pedagogické nakladatel'stvo.

[28] Pauliny, E. (1997). Krátka gramatika slovenská. Bratislava, Národné literárne centrum - Dom slovenskej literatúry.

[29] Šimková, M. et al. (2017). Slovenský národný korpus: Texty, anotácie, vyhl’adávania. Bratislava, Mikula.

[30] Slovenský národný korpus - prim-7.0-public-all. Bratislava, Jazykovedný ústav L. Štúra SAV 2015. Accessible at: http: / / korpus.juls.savba.sk. 